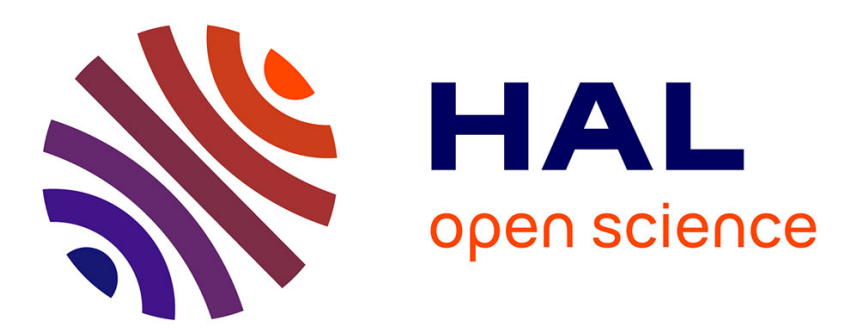

\title{
Globalisation of production and innovation: how outsourcing is reshaping an advanced manufacturing area
}

Lucia Cusmano, Maria Luisa Mancusi, Andrea Morrison

\section{- To cite this version:}

Lucia Cusmano, Maria Luisa Mancusi, Andrea Morrison. Globalisation of production and innovation: how outsourcing is reshaping an advanced manufacturing area. Regional Studies, 2010, 44 (03), pp.235-252. 10.1080/00343400802360451 . hal-00579791

\section{HAL Id: hal-00579791 https://hal.science/hal-00579791}

Submitted on 25 Mar 2011

HAL is a multi-disciplinary open access archive for the deposit and dissemination of scientific research documents, whether they are published or not. The documents may come from teaching and research institutions in France or abroad, or from public or private research centers.
L'archive ouverte pluridisciplinaire HAL, est destinée au dépôt et à la diffusion de documents scientifiques de niveau recherche, publiés ou non, émanant des établissements d'enseignement et de recherche français ou étrangers, des laboratoires publics ou privés. 


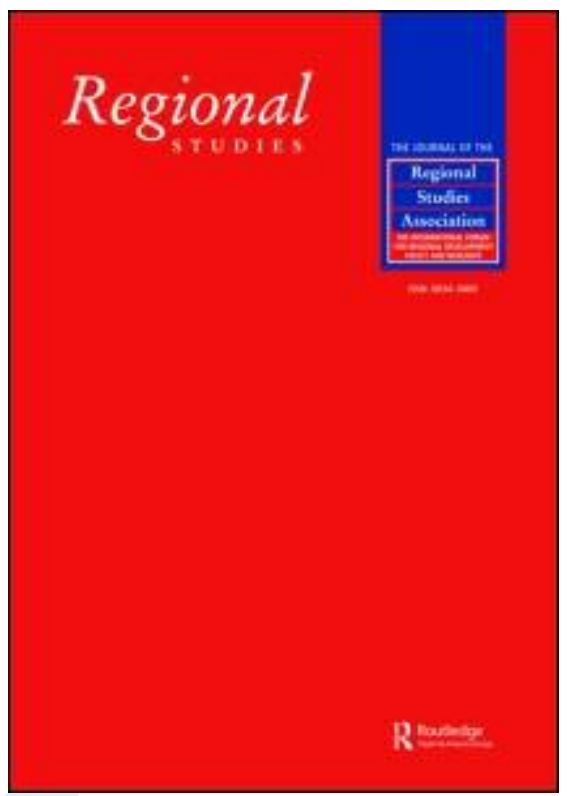

Globalisation of production and innovation: how outsourcing is reshaping an advanced manufacturing area

\begin{tabular}{|r|l|}
\hline Journal: & Regional Studies \\
\hline Manuscript ID: & CRES-2007-0197.R2 \\
\hline Manuscript Type: & Main Section \\
\hline JEL codes: & $\begin{array}{l}\text { D21 - Firm Behavior < D2 - Production and Organizations < D - } \\
\text { Microeconomics, F23 - Multinational Firms | International Business < } \\
\text { F2 - International Factor Movements and International Business < F } \\
\text { Firm Objectives, Organization, and Behavior < L - Industrial } \\
\text { Organization, O32 - Management of Technological Innovation and } \\
\text { R\&D < O3 - Technological Change|Research and Development }<\text { O O } \\
\text { - Economic Development, Technological Change, and Growth }\end{array}$ \\
\hline Keywords: & $\begin{array}{l}\text { Outsourcing, Offshoring, Regional production system, } \\
\text { Manufacturing industry, Italy }\end{array}$ \\
\hline
\end{tabular}

\section{S ScholaroNE \\ Manuscript Central}


Globalisation of production and innovation:

How outsourcing is reshaping an advanced manufacturing area

\author{
Lucia Cusmano $^{\text {abi }}$ \\ lcusmano@eco.uninsubria.it
}

Maria Luisa Mancusia ${ }^{\text {ac }}$

marialuisa.mancusi@unibocconi.it

Andrea Morrison $^{\text {ad }}$

a.morrison@geo.uu.nl

\author{
a CESPRI - Bocconi University, via Sarfatti 25, 20136 Milan, Italy \\ b Insubria University, via Monte Generoso 71, 21100 Varese, Italy \\ c Bocconi University, via Sarfatti 25, 20136 Milan, Italy \\ d Department of Economic Geography, Utrecht University, Heidelberglaan 2, 3508 TC \\ Utrecht, The Netherlands
}

First received: July 2007

Accepted: April 2008

\begin{abstract}
This paper investigates the determinants and the spatial and functional dimensions of firms' outsourcing. Based on a large survey of manufacturing firms in Lombardy, the analysis shows that outsourcing is remarkably wide across sectors and has a clear regional dimension, concerning highly skilled firms at most. Offshoring is still a minor fraction of the deverticalisation process, largely related to wider strategies of internationalisation by foreign group subsidiaries at intermediate stages of the value
\end{abstract}


chain. The evidence suggests the regional system is inserting onto global knowledge networks, but also points at the risk of "branch plant effects" in high tech segments.

Keywords: Outsourcing, Offshoring, Regional production system, Manufacturing industry, Italy

JEL Classification: D21, F23, L23, O32

La mondialisation de la production et de l'innovation:

comment l'approvisionnement à l'extérieur réorganise une zone industrielle avancée.

Cusmano et al.

Cet article cherche à examiner les déterminants et la portée géographique et fonctionnelle de l'approvisionnement à l'extérieur des entreprises. A partir d'une enquête détaillée des entreprises industrielles situées en Lombardie, l'analyse laisse voir que l'approvisionnement à l'extérieur s'avère très généralisée à travers les secteurs et a une portée nettement régionale en ce qui concerne notamment les entreprises dont la main-d'oeuvre est hautement qualifiée. Les activités offshore représentent toujours une proportion négligeable du processus de désintegration verticale et se rapporte étroitement aux stratégies d'internationalisation des filiales des groupes étrangers aux étapes intermédiaires de la chaîne des valeurs. Les preuves laissent supposer que le système regional s'insère dans des réseaux de connaissance mondiaux, mais indique également la menace que pose des "effets établissement" dans les secteurs à la pointe de la technologie.

Approvisionnement à l'extérieur / Activités offshore / Système de production régional / Industrie / Italie

Classement JEL: D21; F23; L23; O32

\title{
Die Globalisierung von Produktion und Innovation: Wie sich eine fortgeschrittene Produktionsregion durch Outsourcing verändert
}

\author{
Lucia Cusmano, Maria Luisa Mancusi and Andrea Morrison \\ In diesem Beitrag untersuchen wir die Determinanten sowie die räumlichen und \\ funktionellen Dimensionen des Outsourcing von Firmen. Ausgehend von einer \\ umfangreichen Erhebung unter produzierenden Firmen in der Lombardei geht \\ aus der Analyse hervor, dass das Outsourcing in den verschiedenen Sektoren \\ bemerkenswert weit verbreitet ist und eine eindeutig regionale Dimension
}


aufweist, die vor allem Firmen mit hohem Qualifikationsniveau betrifft. Die Verlagerung ins Ausland stellt weiterhin einen kleinen Bruchteil des Devertikalisierungsprozesses dar und ist größtenteils mit den breiter angelegen Internationalisierungsstrategien von Filialen ausländischer Konzerne auf den mittleren Stufen der Wertschöpfungskette verknüpft. Die Belege lassen darauf schließen, dass sich das regionale System in die globalen Wissensnetzwerke einfügt, weisen aber auch auf das Risiko von "Zweigwerkseffekten" in HightechSegmenten hin.

Keywords:

Outsourcing

Verlagerung ins Ausland

Regionales Produktionssystem

Produzierende Industrie

Italien

JEL Classification: D21, F23, L23, 032

Globalización de producción e innovación: cómo la contratación externa remodela un área manufacturera avanzada

Lucia Cusmano, Maria Luisa Mancusi and Andrea Morrison

En este artículo investigamos los determinantes y las dimensiones espacial y funcional de la contratación externa de empresas. Basándonos en un importante estudio de empresas manufactureras de Lombardía, en este análisis mostramos que la contratación externa está muy extendida en todos los sectores y tiene una clara dimensión regional, sobre todo con respecto a las empresas altamente cualificadas. La externalización de servicios representa todavía una fracción menor del proceso de desverticalización, y en gran medida relacionada con estrategias más extensas de la internacionalización por parte de filiales de grupos extranjeros en fases intermedias de la cadena de valores. La evidencia indica que el sistema regional se inserta en las redes de conocimiento globales pero también señala el riesgo de "efectos de las sucursales" en segmentos de alta tecnología.

Keywords:

Contratación externa

Externalización de servicios

Sistema de producción regional

Industria manufacturera

Italia

JEL Classification: D21, F23, L23, 032

Acknowledgements: 
The authors would like to thank participants at ProAct Conference (Tampere), International Schumpeter Society Conference (Nice), EARIE Conference (Amsterdam), EMAEE Conference (Manchester) and in seminars and workshops at Università di Roma Tre (Roma), Cespri-Università Commerciale “L. Bocconi” (Milano), Università of Salento (Lecce), Università del Piemonte Orientale (Novara), Beta-Université Louis Pasteur (Strasbourg). Financial support from IReR-Lombardia is gratefully acknowledged. Andrea Morrison also acknowledges funding from the Italian Ministry of Education, University and Research (PRIN 2005 on "Fragmentation and local development"). 


\section{1- Introduction}

Over the last decades, industrial restructuring in the form of outsourcing has been emerging as a defining character of the capitalist dynamics, transforming business models and affecting the spatial structure of industrial systems. In particular, the international dimension of outsourcing (offshoring) has been lately drawing much attention at both the analytical and policy level, as a key driver of changes in the competitive position of advanced and emerging regions (UNCTAD, 2004; OECD, 1998; AMITI and WEI, 2005).

The outsourcing phenomenon in advanced regions dates back to the mid 70s and has been accelerating during the 1990s (GEREFFI and STURGEON, 2004), signalling the "deverticalization" of the modern corporation (CHANDLER, 1977). Moreover, the structure of outsourcing has been widening in functional terms, as outsourcing strategies no longer concern only, or mostly, fairly specialised repetitive tasks in production and assembly. Rather, outsourcing increasingly involves services of various type and content, including sensitive functions and knowledge-intensive tasks, such as design and R\&D (HOWELLS, 2000; LEIBLEIN et al., 2002). As a consequence, the increasing "distributedness" of production processes is followed (and affected) by a growing "distributedness" of knowledge-intensive functions and innovation processes, so that value creating resources and capabilities ever more frequently reside across the boundaries of the firm (COOMBS and METCALFE, 1998).

The functional breadth of the outsourcing phenomenon is but one dimension of the complex emerging trend, to which the spatial dimension should be added. On the one hand, the internationalisation of value chains, or global "fragmentation", has been attracting much media hype, but also increasing theoretical interest, because of its consequences on the positioning of countries in the international division of labour (e.g. 
FEENSTRA and HANSON, 1996; ARNDT and KIERZKOWSKI, 2001; GROSSMAN and HELPMAN, 2002). On the other hand, agglomeration advantages and clustercentred flexible specialisation in core-regions are being re-interpreted (e.g. SCOTT, 1988; GAROFOLI, 2002; BOSCHMA; 2004), as their relevance and geographical scale are affected themselves by post-Fordist dynamics (PHELPS, 2004; TORRE and RALLET, 2005).

Although lively, the theoretical and policy debate has found still limited empirical application for two main reasons. First, empirical investigations have been mainly directed at specific sectors or local production systems (e.g. CORÒ and GRANDINETTI, 1999; AMIGHINI and RABELLOTTI, 2006), specific functions, as in the case of the growing literature on business service externalisation (e.g. O'FARRELL et al., 1993; BEYERS and LINDAHL, 1996; COE, 2000) or specific actors, such as multinational branch plants or service-related headquarters (e.g. PHELPS, 1993; PERKMANN, 2006). Second, quantitative studies based on large panel datasets have been mostly based on very broad definitions of outsourcing, rarely differentiating externalisation of activities from more general purchasing strategies in a "make or buy" framework, and have often employed data at a high (mostly industry) level of aggregation ${ }^{\text {ii }}$.

The present paper contributes to fill this gap by investigating the diversified patterns of externalisation across manufacturing industries and business actors in an advanced area, Lombardy, the Italian leading economic region, which represents a mature and highly heterogeneous industrial system, where large corporations specialised in high-tech sectors coexist with traditional industrial districts populated by small firms.

Drawing on original and representative firm-level survey data, the paper explores the extent of the externalisation practices, detailing direction, breadth and depth of outsourcing strategies, thus providing an original empirical contribution to the 
outsourcing debate. In particular, the international outsourcing of production, services and $R \& D$ activities is confronted with regionally contained dynamics, and the characteristics of business actors driving the process at different spatial levels are explored. In doing so, the paper adds to the sparse empirical literature on the determinants of outsourcing and offshoring at the firm-level (GIRMA and GÖRG , 2004; GÖRG et al. 2004; GROSSMAN and HELPMAN, 2002; SWENSON, 2004; TOMIURA, 2005), and provides original insights for discussing both the implications at the system level and the related arguments proposed by the relevant literature.

The paper is organised as follows. Section 2 summarises the main issues emerging from the literature and policy debate about outsourcing and off-shoring, focussing on the motives for outsourcing and their relationship with its direction (local vs. international outsourcing), depth (total vs. partial outsourcing) and breadth (scope of functional outsourcing). Section 3 presents the survey methodology and the dataset. Section 4 provides an extensive description of outsourcing patterns in Lombardy, across industries and activities. Section 5 focuses on the characteristics of firms driving the process of deverticalisation, presenting an econometric assessment which differentiates between regional and international outsourcing. Section 6 concludes, discussing implications of the observed trend for the regional system evolution and competitiveness.

2. Outsourcing: economic drivers, spatial dimension and firm characteristics

Different strands of literature, ranging from management approaches, to transaction cost economics and more regional oriented studies, have investigated the factors underpinning firms' decisions to outsource their internal activities, the spatial dimension of the externalisation process and the associated firms' characteristics. However, while the motives for outsourcing and its geographical scope are often (and naturally) studied 
together in the literature, the interpretation of fragmentation trends and spatial restructuring in terms of firm-level characteristics is more recent and mostly discussed in empirical contributions.

Cost factors have featured prominently in the debate about vertical disintegration and its spatial dimension. The transaction cost analytical framework represents in this sense the main theoretical reference, suggesting that firms externalise activities when and where external provision is less expensive than internal procurement (WILLIAMSON, 1985). Scott (1988) argues that in capitalist societies the organisation of production, including its spatial distribution, is constantly scrutinised by firms with the purpose of reducing costs. This often implies seeking for factor price differences across locations, countries or regions, particularly, though not exclusively, when labour-intensive production and assembling are concerned. Accordingly, the spatial distribution of outsourcing reflects factor cost differentials, involving peripheral areas of advanced countries or developing regions, which attract routinised unskilled production, while core-regions dominate in unstandardised skilled labour or contact-intensive activities, characterised by high unit linkage costs (LEUNG, 1993). The recent integration of international markets and the increasing competitive pressure they have brought about help explaining the late upsurge in international subcontracting towards low-cost areas (FEENSTRA, 1998). Evidence of total outsourcing at international level comes especially from traditional manufacturing sectors, heavily hit by competition from emerging economies. Costcutting strategies have been favouring the emergence of "lean and mean" global players, transforming producers into international buyers, which co-ordinate global production networks of subcontractors in many different countries (GEREFFI, 1999).

The transaction cost perspective also emphasises the additional cost burden associated with international outsourcing, as spatial dispersion can result in longer lead times, larger inventories, communication and co-ordination problems, difficulties in 
contractual specification and monitoring, which tend to rule out distant subcontracting of non standardised functions (GILLEY and RASHEED, 2000). The transaction cost approach therefore suggests that outsourcing to local suppliers is to be preferred when market relationships are less expensive at closer distance. In the case of advanced high cost areas, proximity is an advantage in terms of contractual specification and monitoring, which are all the more relevant when non-standardised tasks or specific assets are concerned. As a consequence, advanced services tend to locate much close to their primary source of demand, since they entail significant customisation, frequent contacts between users and providers, or even simultaneous production and consumption (HOWELLS, 2000).

However, as standardisation and asset specificity evolve, international outsourcing concerns a wider range of functions and products, including apparently strategic activities, such as design and R\&D. In this respect, Freeman and Soete (1997) underline that not all R\&D has high degrees of uncertainty and complexity attached to it. Indeed, several knowledge intensive activities have been undergoing a process of "commoditisation", generally reflected in declining terms of trade and harsher price competition, even in segments of high tech industries (MINIAN, 2006). As such, firms find it preferable to outsource these activities to suppliers who can offer standardised products or services at a lower cost. In addition, improved communication technologies make codification easier and increase the ability of firms to monitor and compare the quality of external suppliers, thus creating alternatives to direct or close control and minimising the need for close user-producer interactions (TETHER et al., 2001; NARULA, 2001). "Organized proximity" (TORRE and RALLET, 2005), i.e. common behavioural rules and routines and means for sharing information and knowledge, offers powerful mechanisms for long-distance coordination, thus widening the scope for outsourcing relational intensive activities at international level. 
Cost-advantages related to standardised input provision can also be found in relatively high cost areas, if providers serve a large market and enjoy economies of scale and specialisation, as in the case of territorial agglomeration of clients. This might explain why off-shoring is still, in absolute terms, a limited phenomenon (AMITI and WEI, 2005) and also why, in core regions, outsourcing has been contributing to the expansion of service complexes or thickening of local business service markets (WOOD et al., 1993; ONO, 2007).

Scott (1988) relates the cost-advantages of subcontracting at the local level to selfreinforcing marshallian externalities, as those which characterise urban agglomerations (ILLERIS, 2005) or manufacturing clusters. Marshallian externalities are a multidimensional concept, comprising both pecuniary externalities and knowledge externalities. These are characterised by different tendencies.

On the one hand, pecuniary externalities are considered to be increasingly less important in driving agglomeration of suppliers and, as a consequence, in explaining localised vertical disintegration (PHELPS, 2004; PHELPS and OZAWA, 2003). In fact, improvements in transport and communication technology and infrastructure have reduced the need for geographical proximity. Location in one area does not preclude access to externalities generated in another one, if the two are strongly connected. In this sense, pecuniary externalities are increasingly related to "accessibility" rather than simply "proximity". Indeed, the wider availability of pecuniary externalities tend to act as a centrifugal force, deconstructing traditional industrial agglomerations and changing the scale at which agglomeration advantages are perceived (MARTIN, 1999; PHELPS, 2004).

On the other hand, knowledge externalities and benefits from labour market pooling continue to act as a significant centripetal force, favouring agglomeration of specialised suppliers and flexible specialisation models in core regions (GAROFOLI, 2002). In this 
context, externalisation of production and service activities is mainly driven by motivations other than costs, such as production smoothing, core-competence focus, or expertise- and knowledge-searching strategies.

Production smoothing and the search for flexibility are, according to Beyers and Lindahl (1996), "quasi-cost" factors, in the sense that they are indirectly related to costreduction strategies. In environments characterised by unstable market conditions, subcontracting emerges as a mechanism for rapidly adjusting to changes in the market, without harmful effects on the level of efficiency (AJAYI, 2005). It stands as a defining character of flexible regimes of capital accumulation, in which internal economies of scale are largely replaced by external economies (SCOTT, 1988; STORPER and SCOTT, 1989). Production smoothing often takes place at the local level, as rapidity and monitoring of quality control are greatly important, unless bulky and highly standardised activities are involved. However, it is a strategy which typically involves "capacity" or concurrent subcontracting (IMRIE, 1986: 956), rather than downsizing through externalisation.

Externalisation is more likely to occur in rapidly evolving markets, which require innovative responsiveness, feeded by specialised providers and integration of different mixes of information and expertise (COFFEY and BAILLY, 1992). As products become more sophisticated and production relies on an increasing range of specialised technological understanding, firms can hardly develop internally all the capabilities and competences required to bring a product to the market. Especially in environments characterised by strong competition and short product life cycle, firms devote internal resources to strengthen their core business, while outsourcing non-core activities. This occurs, for instance, in the case of ancillary services, which are usually labour intensive (ABRAHAM and TAYLOR, 1996), but also for those complex activities in which firms would be unable to keep the pace with changes and challenges posed by specialised 
suppliers. In this case, subcontracting to external specialised providers responds to the related needs of strengthening core competences, diverting resources and attention from non-core activities, and accessing highly specialised expertise, which complement inhouse capabilities.

The expanding need for specialised knowledge also explains the widening functional scope of outsourcing decisions, which increasingly involve non-manufacturing functions (WOOD, 1991). Indeed, outsourcing of service activities to specialised suppliers has been a hallmark of recent industrial restructuring in advanced regions, concerning an ever larger range of service functions ${ }^{\mathrm{iii}}$. Business service functions are becoming increasingly sophisticated and manufacturing firms generally lack resources and strategic incentives to invest in their development (COE, 2000). Total outsourcing of services is commonplace for SMEs, which, by definition, have a limited amount of resources to invest and little scope for economies of scale in the intra-organisational provision. However, in advanced areas, where manufacturing competitiveness increasingly depends on knowledge contents, even large corporations may be unable to produce innovative services and normally refer to external knowledge intensive providers for expertise and consultancy (WOOD et al., 1993), although the resulting relationship rarely takes the form of "pure" service externalisation (BEYERS and LINDAHL, 1996). More often, and especially when knowledge intensive or strategic activities are involved, we observe complementary relationships between in-house departments and specialised suppliers (MAHNKE, 2001). In such cases, outsourcing responds to the need of reaping specialisation gains while exposing to a variety of learning experiences. The risk associated with this strategy is that, if it implies dismissal of strategic capabilities, it may also undermine firms' absorptive capacity (MAHNKE, 2001). This is one of the firm-level characteristics that have attracted the attention of 
recent contributions interpreting the trends of fragmentation and spatial restructuring in terms of features of business players which are driving the outsourcing dynamics.

Firm-specific factors such as size (ABRAHAM and TAYLOR, 1996; MARTINEZ and RUBIERA, 2004; KIMURA, 2002; GIRMA and GÖRG, 2004; TAYMAZ and KILIÇASLAN, 2005; MAZZANTI et al. 2006), productivity (KIMURA, 2002; TOMIURA, 2005; OLSEN, 2006), R\&D intensity (BARNEY, 1999; MAHNKE, 2001; MOL, 2005), human capital (TOMIURA, 2005; MAZZANTI et al., 2006), export or FDI strategies (GEREFFI, 1999; GROSSMAN and HELPMAN, 2002; TOMIURA, 2005) are discussed and related to the cost arguments, specialisation or knowledgesearching strategies commented above ${ }^{\mathrm{iv}}$. Evidence on the matter is however mostly anecdotic or based on case studies. Investigation based on large firm-level datasets is in its early stages, often referring to specific industries or local production systems.

\section{Sample identification and survey method}

The empirical analysis draws on a representative and large dataset concerning the main manufacturing sectors of Lombardy. The region represents a fully fledged and mature industrial system, recently affected by substantial tertiarisation, although still exhibiting important remnants of a manufacturing core. The region accounts for about 1/5 of the Italian GDP and is leading the country in most of the rankings related to innovation and internationalisation, although such leadership has been gradually eroding at the national level, and the region has been lately losing ground with respect to other advanced European areas (CUSMANO and MALERBA, 2005). Its openness makes it particularly exposed to international changes and pressures, which affect in different manners its highly heterogeneous sectors of specialization and productive milieux, characterised by 
a significant presence of both high tech multinationals and small firm-based traditional industrial districts ${ }^{\mathrm{v}}$.

The target sample of 1200 firms is drawn from the national firm Census (ISTAT, 2001) and is stratified according to geographical location, manufacturing activity and firm size.

Geographical stratification groups into four macro areas neighbouring provinces, which exhibit significant within-group similarities in terms of productive specialization: a) Milan; b) North-East (Varese, Como, Lecco and Sondrio); c) North-West (Brescia and Bergamo); d) South (Pavia, Lodi, Cremona, Mantova).

Stratification based on manufacturing activity is obtained with reference to eight macrosectors:

a. Energy \& Chemistry: mining, extraction of crude petroleum and gas, coal and lignite, chemistry, rubber and plastic, electricity, gas and water supply;

b. Food \& Tobacco: food products, beverages and tobacco;

c. Textile \& Clothing: textile, wearing apparel, tanning and leather, footwear;

d. Wood \& Furniture: wood and product of wood, furniture;

e. Paper \& Publishing: publishing, printing and reproduction of recorded media;

f. Mechanics \& Transport: basic metals, other non metallic mineral products fabricated metal products, machinery and equipments, motor vehicles, jewellery;

g. Electronics \& Optics: electrical machinery, radio communication equipment and apparatus, precision and optical instruments, watches and clocks, accounting and computing machinery;

h. Construction: Construction and housing. 
Size dimension stratification is based on the number of employees and is built around five cells: (1) 6-9; (2) 10-49; (3) 50-249; (4) 250-499; (5) more than 500. These size classes are based on the EU classification, but explicitly exclude micro-firms (i.e. firms with less than six employees).

The number of firms in each stratum of the target sample has been obtained assuring proportionality to the total number of employees in the same stratum of the population. However, appropriate balancing criteria have been adopted in order to avoid strata with small or medium sized firms to have an insufficient number of firms and ensure a satisfactory estimates' precision.

Data were collected through an original firm-level survey conducted in 2005. Each firm in the target sample was contacted by a survey agency, which interviewed via telephone either the chief executive officer, the managing director, or the chief administrative officer. A second target sample was available to the survey agency to replace non respondents. This allowed obtaining a final sample of 1,148 regionally-based firms, which corresponds to a response rate equal to $96 \%$. The sample industry and size composition is reported in Table 1, which shows that the Mechanics \& Transport macro-sector accounts for the relative highest share of firms in the sample (34.8\%), followed by Textile \& Clothing (14.5\%), Energy \& Chemistry (14.5\%) and Construction (12.5\%). The table also reports the response rate by sector, which shows that firms from Wood \& Furniture and Construction were used by the survey agency to replace non respondents in other sectors. As a consequence, appropriate survey estimation methods are employed in the empirical analysis to control for the potential bias originating from this non-response/over-response bias.

\section{TABLE 1}


The sample is mostly composed of small and medium-sized firms (about $50 \%$ of our firms belong to the 10-49 employees class). The share of SMEs is particularly dominant in the Wood \& Furniture industry and in Construction, where about $2 / 3$ of the firms have less than 50 employees. On the other hand, a non-negligible share of large firms characterises a few sectors, such as Energy \& Chemistry, Paper \& Publishing and Mechanics \& Transport (Figure 1).

\section{FIGURE 1}

4. Outsourcing patterns in Lombardy: breadth, depth and internationalisation

The survey conveys information on firms' outsourcing decisions, where outsourcing is intended here as the procuring of activities originally performed internally. More specifically, the respondent was first asked to indicate which functions the firm performs in-house, differentiating among the following functional categories: (a) production and assembling; (b) R\&D and design; (c) services (IT, personnel administration, logistics and distribution, packaging, maintenance). For each function the respondent was then asked to specify if activities originally performed within firm boundaries had been contracted out. If so, the respondent was also asked to indicate whether the contractor is located in Lombardy, in another Italian region or abroad. These sets of questions allow us to draw a picture of both the geographical dimension of outsourcing and the depth of the phenomenon across functions.

The outsourcing phenomenon appears to have pervasively affected the manufacturing system in Lombardy. In fact, outsourcing involves nearly half of the firms in the sample, and is uniformly distributed across industries. The two significant exceptions are Paper \& Publishing and Electronics \& Optics, which represent, respectively, the 
upper $(60.7 \%$ of firms outsourcing) and the lower $(42.5 \%)$ tails of the distribution (Table 2).

TABLE 2

\section{Direction}

Outsourcing has a clear regional dimension: on average more than $40 \%$ of firms $(83 \%$ of outsourcers - i.e. firms outsourcing at least one function) refer to a regional supplier for some of the functions they have decided to contract out. This pattern prevails in sectors which are at the heart of regional industrial districts, such as Wood \& Furniture, Textile \& Clothing and Mechanics \& Transport, or which are mostly a locally based business, such as Construction. This evidence is consistent with contributions stating that local knowledge and supply chains, inter-firm and inter-personal networks substantially increase the scope of outsourcing (e.g. MORGAN, 1997).

\section{FIGURE 2}

Furthermore, relying exclusively on regional contractors is effectively the most common option (Figure 2). This strategy is indeed followed by $30.8 \%$ share of firms in the sample (61.8\% of all outsourcers). Again, it is the locally based Construction industry which is mostly involved in self-contained local networks of contracting. Regional outsourcing is an exclusive strategy also for a significant share of firms in Mechanics \& Transport. Thus, restructuring through externalisation mainly generates localised linkages. As mentioned, this can be related to the presence of large local clusters, which are a distinctive feature of the competitive system of Lombardy in this and other traditional sectors and which are likely to capture the outsourced functions. In this sense the trend seems to be driven by highly localised advantages from division of labour and 
complementary specialisation, rather than by the search for cost differentials across space.

The share of firms that rely on outsourcing to other Italian regions stands at significant distance, both in traditional sectors and in high tech ones (Table 2). Indeed, in Electronics \& Optics, international value chains attract outsourced activities to a larger degree than national producers. This high-tech industrial area is however quite an exception in the regional fragmentation dynamics. Off-shoring is, in fact, still a limited phenomenon, accounting for a minor part of the overall outsourcing trend. The participation to international fragmentation processes concerns less than $8 \%$ of the firms in the sample (and 16\% of the actual outsourcers) and is unevenly distributed across industries. Two highly different sectors stand well above the average: Electronics \& Optics and Textile \& Clothing. The share of outsourcers that have been contracting activities abroad is equal to nearly $1 / 3$ in the first and $1 / 4$ in the latter. It is therefore in these two sectors that the externalisation process mostly reflects integration into the increasingly international division of labour.

\section{Breadth and depth}

It is to be expected that the regional or international dimension of the outsourcing process is related to the content of the activities concerned, and that those activities are (performed and) outsourced differently across industries, reflecting industry differences in terms of competitive factors, competitive strategies of the firms and comparative advantages of the territories. Accordingly, we differentiate the functions being outsourced and explore the relationship between outward orientation (or regional embeddeness) and type of activity, always taking into account industry differences.

We analyse the breadth and depth of outsourcing in relation to the three functional categories of production and assembling, R\&D and design, and services. First of all, it 
is important to underline that firms have been performing these functions to a different degree. Production/assembling activities are, as expected, the defining character of the manufacturing system in Lombardy and, even when firms decide to turn to external suppliers for activities they used to perform in-house, outsourcing rarely implies complete disinvestment. As Table 3 shows, only a very minor share of firms (3\%) never carried out any production activities, whereas $94 \%$ exhibit dedicated functions. For nearly $74 \%$ of firms, production or assembling have not been affected by any type of outsourcing, while the remaining $20 \%$ of firms with dedicated functions have partially outsourced them. Only $3 \%$ of firms in the sample have been going through complete disinvestment in manufacturing activities. "Hollow companies" (FREEDMAN, 2004), that is, firms turned into pure coordination structures, are therefore still rather infrequent.

Indeed, the strategy of full disinvestment (total outsourcing) concerns a small share of firms across all the functions examined. The area in which turning to external suppliers most frequently implies that firms dismiss the related function is $R \& D$ and design. Among firms that have been performing some types of research activity (75\% of the sample) $)^{\mathrm{vi}}$, very few outsourced any of them, preferring to keep this strategic (and sensitive) function close to the in-house core. However, when outsourcing took place, it has been more likely, compared to other functions, that it turned into total outcontracting. In other words, partial outsourcing is relatively less common for R\&D than for other functions.

This evidence is at odds with the prediction of the resource-based view of the firm, which would suggest that complementary relationships between in-house departments and specialised suppliers are more likely to be observed in the case of knowledgeintensive activities (MAHNKE, 2001), as dismissing these functions undermines firms' absorptive capacity. This is less the case, if $R \& D$-related activities present low degrees 
of uncertainty and complexity (FREEMAN and SOETE, 1997) or in environments characterised by "open innovation models" (LAURSEN and SALTER, 2004), which would however require close ties and proximity (SORENSON et al., 2006).

\section{TABLE 3}

This evidence can be further qualified by considering the direction of outsourcing, in both spatial and organisational terms. Table 4 presents the relevance of regional vs. international suppliers, considering "potential outsourcers" only (i.e. firms that have/had functions related to the area under investigation). For instance, nearly $40 \%$ of the firms with in-house services experienced de-verticalisation. Among them, $85 \%$ referred, at least for one of the externalised activities, to regional suppliers. This suggests that the local markets for services are thick, although exclusively regional outsourcing is less common, that is, most firms resort to service providers located at various sites, across the regional and, to a lower degree, the national border.

This evidence is consistent with the observation in the literature that localised externalisation is one of the driving forces of service markets growth in core regions (O'FARRELL et al., 1993, COE, 2000).

TABLE 4

As far as $R \& D$ is concerned, over $82 \%$ of the firms performing some type of R\&D activity has not experienced any (even partial) outsourcing. Regional markets are nevertheless relevant as location of suppliers, but also the share of firms referring to 
foreign contractors is similar to that observed in production and assembling. This result however hides significant inter-industry differences (Figure 3). Industries exhibiting a relatively higher percentage of firms outsourcing abroad include such different areas as Textile \& Clothing and Electronics \& Optics. When uncovering the details about the nature of the outsourced activities, it is however evident that the similar trend is related to different strategies (and, supposedly, determinants). For Textile \& Clothing, offshoring consists mainly in international outsourcing of production and assembling activities and, to a lesser extent, services. The Electronics \& Optics industry is significantly more oriented towards international outsourcing of R\&D and design, although the off-shoring of production activities is also non-negligible. If nearly half of the R\&D outsourcers in the industry outsourced abroad, about $1 / 3$ of those outsourcing production turn to international suppliers. Energy \& Chemistry is the other industry whose international outcontracting is above the average in all functions and, particularly, in R\&D. At the other extreme, the Construction and Wood \& Furniture industries refer almost entirely to the domestic market.

The high share of international outsourcing in knowledge-intensive activities is partially to be related to strategies of multinational groups. In fact our data also show that, when offshored, the R\&D function is indeed transferred to another group affiliate abroad (or the foreign headquarter) more frequently than in the case of production and services ${ }^{\mathrm{vii}}$. This seems to suggest that regional high-tech industries are affected by a sort of "branch plant effect", which is generally associated with peripheral areas (PHELPS, 1993). Multinational branch plants are "outsourced" of their R\&D functions by headquarters, which implies a lower degree of regional embeddedness in the forms of localised knowledge-intensive linkages.

\section{FIGURE 3}


5. Firm-level characteristics and the geographical dimension of outsourcing

5.1 Econometric model and description of the variables

Following recent empirical contributions on the determinants of outsourcing (GIRMA and GÖRG 2004; MAZZANTI et al., 2006; MOL, 2005; TOMIURA, 2005), we model outsourcing decisions by firms as a function of a number of variables reflecting firmspecific characteristics, while accounting for sectoral specificities. We estimate different probit models, in order to assess the possible distinct relevance of these characteristics for the inward (regional) and the outward (foreign) orientation of the outsourcing strategy. In the first model, we consider exclusively regional outsourcing: our dependent variable is a dummy equal to one when the firm has been undertaking regional outsourcing only. The second model describes the probability of a firm performing international outsourcing: here the dependent variable is a dummy equal to one when the firm has outsourced some activity to another country. Finally, for the sake of comparison, we also estimate a third model where the dependent variable is a dummy equal to one when the firm performs any kind of outsourcing, i.e. independently of the localisation of the contractor. All models are estimated accounting for the effects of sampling design and response on population estimates by using pseudo-maximum likelihood methods and allowing for probability sampling weights and stratification.

We first test the explanatory power of a basic set of quantitative variables, also obtained from the survey (Table 5). The first explanatory variable, PRODUCTIVITY (sales over employees), is intended to test the hypothesis that firms engaged in outsourcing have higher productivity than vertically integrated firms (OLSEN, 2006). The rationale is that firms outsource activities in which they are less efficient or for which they do not enjoy 
much competitive advantage, based, for instance, on unique knowledge or skills, while focusing on their core competencies or reallocating resources towards activities with greater value added, and thus gaining in productivity. Only very few studies have analysed the reverse direction of causality, providing however no clear cut evidence (KIMURA, 2002; TOMIURA, 2005). For example Tomiura (2005) points to a greater marginal relevance of productivity for international outsourcing than for generic outsourcing, that would be explained by the high fixed costs for foreign contracting, which makes this alternative viable for rather productive firms. Notice that our measure of labour productivity could be positively related to outsourcing also because firms contracting out their activities usually reduce the number of employees, while sales remain constant.

\section{TABLE 5}

The second explanatory variable, RDI (R\&D over sales), measures R\&D intensity, whose impact on outsourcing cannot be straightforwardly signed (MAHNKE, 2001; MOL, 2005). The conventional view would argue that R\&D intensive industries tend to be vertically integrated in order to recover the high sunk costs generated by $R \& D$ investment. A further and complementary argument, based on the transaction cost approach, maintains that industries dealing with complex products face severe incentive and appropriability problems, which they tend to solve through vertical integration (MOL, 2005; TEECE, 1986). On the other hand, R\&D intensity would be associated to extensive outcontracting in the literature conceiving the firm as an open platform, developing external networks, in particular international ones, to access relevant capabilities, rather than building them internally (BARNEY, 1999). The growing complexity of technologies is one of the key reasons for firms to search for external sources of knowledge (BRUSONI et al., 2001) and relationships with suppliers represent important channels for accessing capabilities. Local outsourcing provides 
advantages of generally lower transaction costs and continuous interaction, favouring interactive learning and incremental change. On the other hand, international outsourcing can be aimed at entering global knowledge networks, and recent advances in communication technologies have made this easier (MOL, 2005).

A further explanatory variable is a measure of firm size (SIZE), here evaluated in terms of number of employees. There seems to be disagreement on the direction of the impact of size. The core competence literature, for instance, would indeed suggest that small firms are more likely to outsource, since they have a strong incentive to devote their limited internal (physical, financial and intangible) resources to core activities and bring out non-core ones (ABRAHAM and TAYLOR, 1996; CORÓ and GRANDINETTI, 1999). In the case of local systems, regionally confined outsourcing by SMEs is to be interpreted in the framework of a strong division of labour, which allows local producers to enjoy increasing returns from specialisation, and the local system to achieve a high degree of "flexible specialisation" (GAROFOLI, 2002). On the other hand, small firms are expected to outsource fewer activities, as they have a smaller scope to start with, and, especially as far as service activities are concerned, fewer and simpler needs than large firms (MARTINEZ and RUBIERA, 2004). The positive relation between firm size and outsourcing is supported by the idea that subcontracting is a strategy of "production smoothing", which allows large firms' to reduce costs and enhance flexibility (IMRIE, 1986; KIMURA, 2002; TAYAZ and KILIÇASLAN, 2005). The effect of size has been tested by some recent empirical works (GIRMA and GÖRG, 2004; MAZZANTI et al. 2006), which however do not provide clear cut evidence.

The explanatory variable $H K$ (share of employees having secondary education) is meant to characterise the firm human capital endowment. Cost saving strategies would suggest a positive relationship between human capital and outsourcing in general. The rationale is that firms employing high skilled workers pay efficiency wages and are not able to 
pursue different wage strategies. However, in order to save costs, they would be keen to outsource peripheral activities for which they employ workers that are paid above the market rate efficiency wage. On the other hand, the competence perspective points to differentiated effects and to ambiguous empirical outcome. Mazzanti et al. (2006) underline that a high level of skills can represent an important incentive to specialise in knowledge intensive activities, while outsourcing more standard production. However, firms with high skills are less willing to outsource, if this creates the risk of losing some distinctive capabilities, thus impoverishing the organisational competences which are built upon them. Finally, other authors have emphasised that human capital is particularly relevant for contracting internationally. Qualified human skills are in fact deemed essential for engaging in contracting abroad, since this requires human capital intensive activities such as negotiating with partners in foreign languages and concluding contracts under different legal systems (TOMIURA, 2005).

In all specifications we control for industry specific effects and introduce a dummy variable FINAL PRODUCT, which identifies firms engaged in the production of final goods $^{\text {viii }}$. We include this variable to account for the differentiated behaviour of firms operating at different stages of the value chain and we expect a positive relationship between outsourcing and downstream production activities (e.g. final transformation or assembling). This is because downstream producers tend to exhibit a greater scope of activities or functions for which outsourcing can take place. In addition, it is especially in downstream production that outsourcing represents an effective strategy for smoothing production over different subcontractors, thus coping with seasonal or demand peaks (IMRIE, 1986). More broadly, this finding would be consistent with the evidence on cost saving strategies, as pointed out in recent works on subcontracting relationships (TAYMAZ and KILIÇASLAN, 2005). 
We further control for the outward orientation of the firm and for organisational specific effects. The outward orientation of the firm seems to be an important control for offshoring behaviour and is captured by two indicators that should convey information on the firm business experience in foreign countries. EXPI (Export/Sales) represents export intensity, while $F D I$ is an indicator variable, which takes the value 1 if the firm has undertaken foreign direct investment ${ }^{\mathrm{ix}}$. We first control for the relevance of FDI per se, and then we further distinguish between production and/or R\&D FDI (FDI_plant) on the one hand, and the mere opening of a sales office abroad (FDI_sales), on the other hand. The empirical literature suggests a positive relationship between outward orientation and international outsourcing (TOMIURA, 2005), which is consistent with the likely reduction of fixed costs of foreign contracting when firms already have business experience in foreign countries. In addition, Görg et al. (2004) underline the potential advantage for exporters in accessing extensive knowledge on where to procure competitively priced inputs. This is in line with the model by Grossman and Helpman (2002), which stresses the relevance of search costs for international outsourcing. In accordance, we expect both kinds of internationalisation strategies to affect positively the probability of foreign outsourcing, and the productive type of FDI to have a larger effect than the investment in sales units or offices.

As far as organisational specific effects are concerned, we introduce a GROUP dummy, which takes a value equal to 1 if the firm is part of an economic group and 0 otherwise. This variable is further split into the variable SUBSIDIARY, which identifies firms that are subsidiaries in a group, and GROUP_HEAD, which identifies the headquarter ${ }^{\mathrm{x}}$. We expect that being part of a group positively affects outsourcing, as firms are in principle embedded in a larger network of providers and potential clients. In addition, we expect subsidiary firms to be more likely than headquarters to do outsourcing, as the first are generally more involved in production activities, whereas the latter are likely to host 
administrative and often strategic (e.g. R\&D) functions, enjoying economies of scale and scope in the provision of group-wide services. At the same time, being Lombardy a core region characterised by a dynamic business environment and a major tertiary area (Milan), we expect branch plants to rely significantly on local service markets.

\subsection{Results}

Table 6 reports correlations among the main explanatory variables and Table 7 shows the results from different specifications of probit estimation for survey data for each of the three dependent variables specified in the previous section (any outsourcing, exclusively regional outsourcing, international outsourcing $)^{\mathrm{xi}}$.

\section{TABLE 6}

Interestingly, in all regressions human capital appears to be a good and highly significant predictor of outsourcing behaviour. The result is consistent with both the cost saving explanation (GIRMA and GÖRG, 2004) and the idea of specialisation driven by skills. Human capital significance is observed when focussing both on regionally oriented outsourcers and on offshorers, even when outward orientation variables (EXPI, FDI) are taken into account. We can infer that human capital represents an important asset for operating in foreign markets, but also a relevant driver in the regionally based flexible specialisation.

By contrast, productivity does not appear to be significant in any of the specifications tested, which is not surprising since the reverse causality has been in fact rarely observed in the empirical literature ${ }^{\mathrm{xii}}$. Furthermore the result might be affected by the 
prevalence of SMEs in our sample (and in the Lombardy, and more generally Italian, production system), as the effect on productivity induced by the possible employment reduction is likely to be marginal for SMEs.

The R\&D intensity variable (RDI) exhibits a similar pattern of significance. Differently from Mol (2005), we do not find robust evidence that R\&D intensive firms have a higher overall probability to outsource, thus our findings do not support the perspective of increasing specialisation and reliance on external sources by $R \& D$ oriented firms. If $\mathrm{R} \& \mathrm{D}$ intensive firms outsource in order to search for competent external suppliers that provide complementary resources, as suggested by the 'relational view' (MAHNKE, 2001), our findings may suggest that the regional scale is too small for creating a market for competent suppliers (PHELPS and OZAWA, 2003), while in international markets, where competition is harsher, knowledge intensive firms tend to be more sensitive to the appropriability problems entailed by outsourcing.

Size does not appear to be a good predictor for the general strategy of outsourcing. This is in line with the evidence provided by Mol (2005). When specifying the direction of outsourcing, the variable appears to exhibit a positive effect on international outsourcing, that is large firms appear to be significantly more likely to engage in offshoring. This result, which confirms findings in Tomiura (2005), seems to point to an apparently trivial implication, that is, availability of a large pool of resources is relevant for sourcing at the international level. However, the effect of size disappears once we properly account for international orientation of firms through export intensity and FDI. We find that a strong relationship exists between international outsourcing behaviour and foreign business experience, as represented by both export activity (EXPI) and FDI. It is foreign investment in a production or $R \& D$ unit that really matters, while the mere opening of a sales office abroad does not show any effect on the probability to do any kind of outsourcing. 
A striking difference emerges between firms outsourcing at the regional level only and those going abroad when focussing on the final product dummy. This is significant in both cases (under all the specifications tested), but takes a positive value, as expected, only when considering exclusively regional outsourcing. On the contrary, it exhibits a significant negative relationship with offshoring. We maintain this result is only apparently counterintuitive. In fact, it is consistent with findings in the trade literature showing that intra-industry trade currently dominates international trade flows (GROSSMAN and HELPMAN, 2002; MINIAN, 2006). In particular, multinationals develop large networks among their affiliates, which source factories all over the world (GEREFFI, 1999). In this respect, it is worth noticing that the final product variable is still significant and negative for the estimation on the offshoring dependent variable when controlling for group dummies.

Related to the above, being part of a group matters for international outsourcing: we find support to the evidence that group subsidiaries rather than headquarters are the drivers of international outsourcing activities. Furthermore, once we control for foreign ownership by interacting the dummy SUBSIDIARY with a dummy FOREIGN taking value 1 if the firm is controlled by foreign actors ${ }^{\text {xiii }}$, we find that it is foreign ownership of subsidiaries that positively affects the probability of international outsourcing. This suggests that foreign controlled units located in Lombardy "have been outsourced", that is, headquarters of foreign MNEs have either appropriated the function or transferred it to another subsidiary/external firm. This adds to the evidence about R\&D total offshoring by firms in high tech industries in pointing to a sort of "branch plant effect" in knowledge intensive segments (PHELPS, 1993).

TABLE 7 
6. Conclusions

This paper explores the extent of outsourcing from the perspective of individual firms located in an advanced manufacturing area. In doing so the paper contributes to the vast literature on firms outsourcing strategies and in particular to the understanding of the determinants of firms' outsourcing decisions. Results shed light on a number of relevant dimensions of outsourcing (i.e. direction, breadth, depth) and thereby complement and corroborate the prevalently qualitative and anecdotic evidence on this topic.

The first outcome of this investigation clearly indicates that, in the case of Lombardy, outsourcing is remarkably widespread and concerns to a similar extent all industrial sectors. Our findings support previous evidence showing that subcontracting in core regions (e.g. WOOD et al., 1991; COE, 2000; ILLERIS, 2005) is mainly local. Indeed, overall outsourcing has a clear and predominant local dimension in those sectors which are highly rooted in regional clusters. In this sense, it appears that marshallian externalities are still relevant in driving deverticalisation and feeding the local dense web of productive relationships, which constitutes the defining character of the flexible specialisation model (SCOTT, 1988; STORPER and SCOTT, 1989). Our evidence suggests that in this core region externalisation is not leading to a loss of density of those traded relationships that represent the source of local competitive advantage (GAROFOLI, 2002).

Subcontracting in Lombardy (and in core regions) involves services to a large degree. Externalisation of service functions contributes to thickening the local service markets and feeds positive agglomeration effects in advanced areas. In this sense, corecompetence focus, or "quasi-cost" factors (BEYERS and LINDAHL, 1996), and the search for complementary expertise at the territorial level seem to be more relevant than cost rationales. The importance of human capital in explaining regionally based 
specialisation further suggests that local fragmentation is driven by knowledge-oriented players. These actors, mostly downstream producers, maintain some related in-house capabilities, which support flexibility and governance of close ties with selected suppliers (O'FARRELL et al., 1993).

Interestingly, outsourcing in value added services (i.e. R\&D and design), is less common - suggesting that firms are still very much concerned with appropriation problems-, but is relatively more likely to span across regional or even national boundaries.

The implications of our results for regional development - and the broad debate about the impact of globalisation on regional clusters - are of particular interest. The risk of local networks impoverishment has been the focus of much recent debate about distant outsourcing. Regions are depositories of tangible and intangible resources, which mostly reside in local firms and on which localised capabilities are built (BOSCHMA, 2004; MASKELL and MALMBERG, 1999). Distant outsourcing can seriously undermine these capabilities, reduce the local relational density and the internal cohesion of the regional system.

In the case of Lombardy, it seems that externalisation has been adding new ties or reinforcing existing ones in the local production system. Especially in the area of business services, opportunities have been created for focused niche players to enter regional markets. Therefore, it appears the adjustment to global trends has been taking place mostly within the model of flexible specialisation, driven by highly localised advantages from division of labour and complementary specialisation. Insertion into global production networks seems not to have been disruptive of industrial clusters, deepening, rather than weakening, local linkages.

However, the strong inward orientation of the process raises other questions, in relation to the long term development trajectory. In fact, dismantling and relocating activities 
outside a region does not necessarily imply negative effects for the local economy, in terms of efficiency or development dynamics. Outward externalisation can lead to a better allocation of resources, which shift from low yielding activities, or declining sectors, to more productive ones. Furthermore, regions benefit from international outsourcing when firms subcontract to high competent producers and/or markets, which become channels for accessing new knowledge and preventing lock-in effects (CAMAGNI, 1991).

Overall, our analysis indicates that international outsourcing is still a minor part of a wider fragmentation trend, which concerns mainly traditional sectors, such as Textile and Clothing. In this case, international outsourcing consists mainly of the externalisation of production and assembling activities and seems to respond to efficiency seeking strategies, which may positively affect regional dynamics.

However international outsourcing also touches knowledge intensive and large scale sectors. On the one hand, this might favour or strengthen the insertion of the regional system into global knowledge networks. On the other hand, if it implies dismissal of high value added functions or loss of strategic assets at the local level, it might seriously hinder the growth potential of the regional system. Our evidence suggests that the region might indeed suffer from a sort of "branch plant effect" in knowledge intensive segments, as R\&D functions, when outsourced, are more likely to be entirely appropriated by foreign headquarters or research units.

In this late phase of world capitalism, which Scott (2005) describes as marked by intensified regionalisation of production overlaid by a global division of labour, traditional industrial core regions, such as Lombardy, face the challenge of preserving their internal cohesion, while governing their insertion into evolving global networks, counteracting the centripetal forces which are redistributing knowledge intensive functions and redefining the global geography of core and periphery. 
References

ABRAHAM, K. and TAYLOR, S. (1996), "Firms' use of outside contractors: theory and evidence", Journal of Labor Economics, Vol. 14, pp. 394-424

AJAYI D.D. (2005), "Integration, industrial linkages and production subcontracting: an overview", European Journal of Social Sciences, Vol. 1, No 1, pp. 42-61

AMIGHINI A. and RABELLOTTI R. (2006), "How do Italian footwear industrial districts face globalization?", European Planning Studies, Vol. 14, No4, pp. 485-502

AMITI M. and WEI S. (2005), "Fear of service outsourcing: is it justified?", Economic Policy, Vol. 20, Issue 42, pp. 308-347

ARNDT S. and KIERZKOWSKI (EDS.) (2001), Fragmentation: new production and trade patterns in the world economy, Oxford University Press, Oxford

BARNEY, J.B. (1999), "How a firm's capabilities affect boundary decisions", Sloan Management Review, 40 (3), pp. 137-145

BEYERS W.B and LINDAHL D.P. (1996), "Explaining the demand for producer services: is cost-driven externalization the major force," Papers in Regional Science, Vol. 75, No. 3, pp. 351-374

BOSCHMA R. A. (2004), "Competitiveness of Regions from an Evolutionary Perspective”, Regional Studies, Vol. 38.9, pp. 1001-1014.

BRUSONI S., PRENCIPE A. and PAVITT K., (2001), "Knowledge specialization, organizational coupling, and the boundaries of the firm: why do firms know more than they make?" Administrative Science Quarterly 46 (4), pp. 597-621.

CAMAGNI R. (1991), Innovation Networks: Spatial Perspectives, Belhaven, London.

CHANDLER A. (1977), The Visible Hand: the managerial revolution in American business, Belknap/Harvard University Press, Cambridge, MA

COE N.M. (2000), "The externalisation of producer services debate: the UK computer services sector", The Services Journal, 20 (2), pp. 64-81. 
COFFEY W. and BAILLY A. (1992), "Producer Services and Systems of Flexible Production", Urban Studies, 29, pp. 857-868.

COOMBS R. and METCALFE J.S. (1998), "Distributed Capabilities and the Governance of the Firm", CRIC Discussion Paper, No 16, University of Manchester CORÒ G. and GRANDINETTI R. (1999), "Strategie di delocalizzazione e processi evolutivi nei distretti industriali italiani”, L'Industria 4, pp. 897-924

CUSMANO L. and MALERBA L. (2005), "Le sfide strategiche per l'innovazione in Lombardia", in IRER, Lombardia 2005. Società, Governo e Sviluppo del Sistema Lombardo: dieci anni di esperienze, Edizioni Guerini e Associati, Milano

FEENSTRA R.C. (1998), "Integration of trade and disintegration of production in the global economy", Journal of Economic Perspectives, 12 (4), pp. 31-50

FEENSTRA R.C. and HANSON G. (1996), "Foreign Investment, Outsourcing and Relative Wages", in R.C. Feenstra, G.M. Grossman and D.A. Irwin (eds.), Political Economy of Trade Policy: Essays in Honor of Jagdish Bhagwati, MIT Press, Cambridge, MA, pp. 89-127

FREEDMAN P. (2004), "The age of the hollow company", The Sunday Times, April $25^{\text {th }}$

FREEMAN C. and SOETE L. (1997), The Economics of Industrial Innovation, Pinter, London

GAROFOLI G. (2002), "Local Development in Europe: Theoretical Models and International Comparisons", European Urban and Regional Studies, Vol. 9, No 3, pp. 225-239.

GEREFFI G. (1999), "International trade and industrial upgrading in the apparel commodity chain", Journal of International Economics, Vol. 48: 37-70. 
GEREFFI G. and STURGEON T.J. (2004), “Globalization, Employment and Economic Development: a Briefing Paper", Sloan Workshop Series in Industry Studies, Rockport, MA, June 14-16

GILLEY K.M. and RASHEED A. (2000), "Making More by Doing Less: An Analysis of Outsourcing and its Effects on Firm Performance", Journal of Management, Vol. 26 (4), pp. 763-790.

GIRMA S. and GÖRG H. (2004), "Outsourcing, Foreign Ownership, and Productivity: Evidence from UK Establishment-level Data", Review of International Economics, Vol.12 (5), pp. 817-832

GÖRG H., HANLEY A. and STROBL E. (2004), "Outsourcing, foreign ownership, exporting and productivity: An empirical investigation with plant level data"; Research Paper 2004/98, Leverhulme Centre for Research on Globalisation and Economic Policy, University of Nottingham

GROSSMAN G. M. and HELPMAN E. (2002), "Outsourcing in a Global Economy", NBER Working Paper 8728, January

HOWELLS, J. (2000), The Nature of Innovation in Services. Report presented to the OECD "Innovation and Productivity in Services Workshop", Sidney, Australia. (http://www.oecd.org/dsti/sti/industry/indcomp)

ILLERIS S. (2005), "The Role of Services in Regional and Urban Development: A Reappraisal of our Understanding", The Services Industries Journal, Vol.25, No.4, pp. $447-460$

ISTAT (2001), Ottavo Censimento Generale dell'Industria e dei Servizi, Roma, ISTAT KIMURA, F. (2002), "Subcontracting and the Performance of Small and Medium Firms in Japan”, Small Business Economics, Vol. 18, 1-3, pp. 163-175

LAURSEN K. and SALTER A.J. (2004), "Searching high and low: what types of firms use universities as a source of innovation?", Research Policy 33, pp. 1201-1215. 
LEIBLEIN M., REUER J. and DALSACE F. (2002), "Do Make or Buy Decisions Matter? The Influence of Organizational Governance on Technological Performance", Strategic Management Journal 23(9), pp. 817-833.

LEUNG C.K. (1993), "Personal contacts, subcontracting linkages, and development in the Hong Kong-Zhujiang Delta region", Annals of the Association of American Geographers, 83, pp. 272-302

MAHNKE V. (2001), “The Process of Vertical Dis-Integration: An Evolutionary Perspective on Outsourcing”, Journal of Management and Governance 5, pp. 353-379 MARTIN R. (1999), "The new 'geographical turn' in economics: some critical reflections", Cambridge Journal of Economics, 23, pp. 65-91

MARTINEZ ARGÜELLES S.R. and RUBIERA MOROLLÓN F. (2004), "Outsourcing of advanced business services in the Spanish economy: an analysis of the regional effect and others explicative elements", XIV Conference RESER, 23-24 September, Castres MASKELL P. and MALMBERG A. (1999) "Localised Learning and Industrial Competitiveness", Cambridge Journal of Economics, 23, pp. 167-185.

MAZZANTI M., MONTRESOR S. and PINI P. (2006), "The General Profile of the Outsourcing Firm: Evidence for a Local Production System of Emilia Romagna", DRUID Working Paper No. 06-20, Copenhagen Business School, Department of Industrial Economics and Strategy/Aalborg University, Department of Business Studies MINIAN I. (2006), "Nueva división internacional del trabajo: redes, segmentación y localización”, Economia Marche. Review of Regional Studies, No 1, anno XXV, pp. 2752

MOL M.J. (2005), "Does being R\&D intensive still discourage outsourcing? Evidence from Dutch manufacturing", Research Policy 34, pp. 571-582

MORGAN K. (1997), “The learning region: institutions, innovation and regional renewal", Regional Studies, 31, pp. 4191-503 
NARULA R. (2001), “In-House R\&D, Outsourcing or Alliances? Some Strategic and Economic Considerations", in F. Contractor (ed), Valuation of intangible assets in global operations, Quorum Books, Westport, CT

O'FARRELL P.N., MOFFAT L.A.R. and HITCHENS D.M.W.N. (1993), "Manufacturing Demand for Business Services in a Core and Peripheral Region: Does Flexible Production Imply Vertical Disintegration of Business Services?", Regional Studies, Vol. 27.5, pp. 385-400

OECD (1998), Internationalisation of Industrial R\&D: Patterns and Trends, Paris

OLSEN K.B. (2006), "Productivity Impacts of Offshoring and Outsourcing: A Review," OECD Science, Technology and Industry Working Papers 2006/1, OECD Directorate for Science, Technology and Industry, Paris

ONO Y. (2007), "Market thickness and outsourcing services", Regional Science and Urban Economics, 37, pp. 220-238

PERKMANN M. (2006), "Extraregional linkages and the territorial embeddedness of multi-national branch plants: evidence from the South Tyrol region in North-East Italy". PHELPS N.A. (1993), "Branch plants and the evolving spatial division of labour: a study of material linkage change in the northern region of England", Regional Studies, 27(2), pp.87-101.Economic Geography, 82(4), pp. 421-441

PHELPS N.A. (2004), "Clusters, Dispersion and the Spaces in Between: For an Economic Geography of the Banal", Urban Studies, Vol. 41, Nos 5-6, pp. 971- 989 PHELPS N.A. and OZAWA T. (2003), "Contrasts in agglomeration: proto-industrial, industrial and post-industrial forms compared", Progress in Human Geography, Vol. 27, No. 5, pp. 583-604

SCOTT A.J. (1988), "Flexible Production Systems and Regional Development: The Rise of New Industrial Spaces in North America and Western Europe", International Journal of Urban and Regional Research, 12, pp. 171-186 
SCOTT A.J. (2005), "Les moteurs régionaux de l'économie mondiale", Géographie, économie, société, Vol. 7, No 3, pp. 231-253

SORENSON O., RIVKIN J.W. and L. FLEMING L. (2006), "Complexity, networks and knowledge flow", Research Policy 35, pp. 994-1017.

STORPER M. and SCOTT A. J. (1989) "The Geographical Foundation and Social Regulation of Flexible Production Complexes" in Wolch J. and Deer M. (eds.) The Power of Geography. Boston: Unwin Hyman, pp. 21-40.

SWENSON D. (2004), "Entry costs and outsourcing decisions: Evidence from the U.S. overseas assembly provision" North American Journal of Economics and Finance, 15 (3), pp.267-286

TAYMAZ E. AND KILIÇASLAN Y. (2005), "Determinants of Subcontracting and Regional Development: an Empirical Study on Turkish Textile and Engineering Industries", Regional Studies, Vol. 39.5, pp. 633-645

TEECE D.J. (1986), "Profiting from technological innovations", Research Policy, 15 (6), pp. 285-305

TOMIURA E. (2005), "Foreign outsourcing and firm-level characteristics: evidence from Japanese manufacturers", Journal of the Japanese and International Economies, 19 , pp. $255-271$

TORRE A. and RALLET A. (2005), "Proximity and Localization", Regional Studies, Vol. 39.1, pp. 47-59

UNCTAD (2004), “The shift towards services", World Investment Report, United Nations, Geneva

WILLIAMSON O. E. (1985), The economic institutions of capitalism, Free Press, New York.

WOOD P.A. (1991), "Flexible Accumulation and the Rise of Business Services", Transactions of the Institute of British Geographers, New Series, Vol. 16, No 2, pp. 
$160-172$

WOOD P.A., BRYSON J. and KEEBLE D. (1993), "Regional patterns of small firm development in the business services: evidence from the UK", Environment and Planning A, 25, pp. 677-700. 
Figure 1 - Sample composition, by size class (\%) across industries

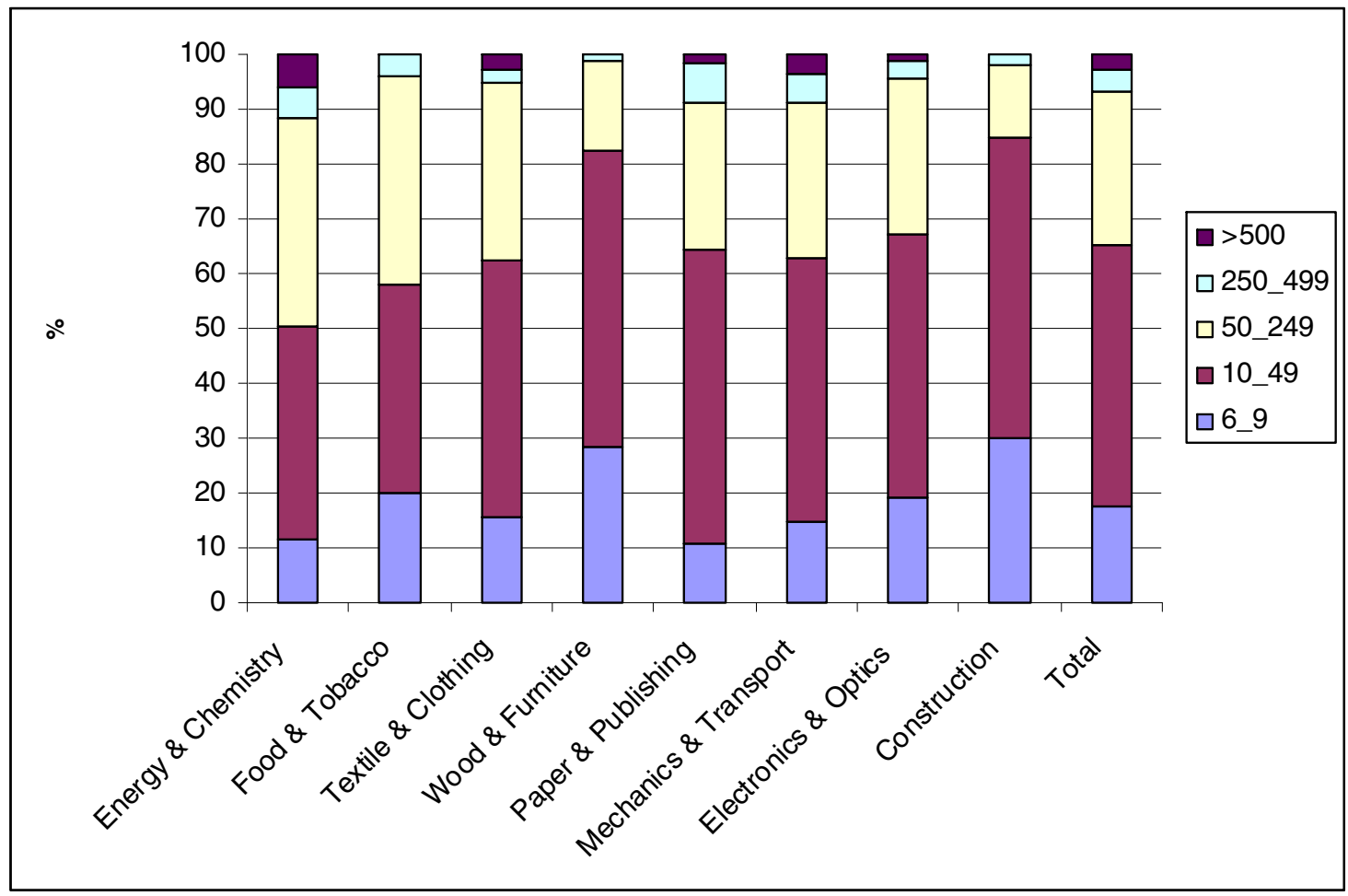


Figure 2 - Regional outsourcing, by industry (\% firms)

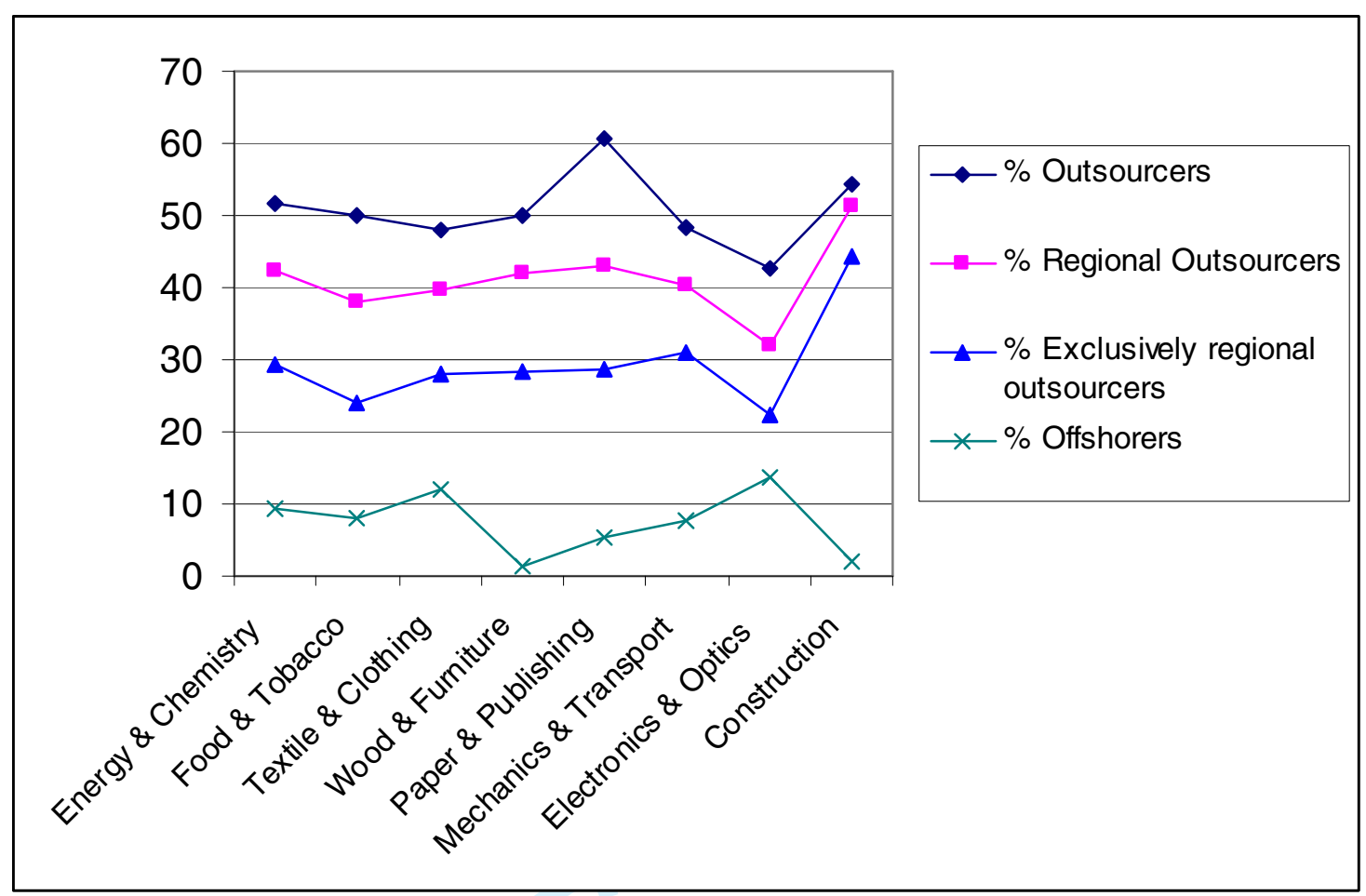


Figure 3 - Breadth of domestic outsourcing and off-shoring, by industry (\% of firms)

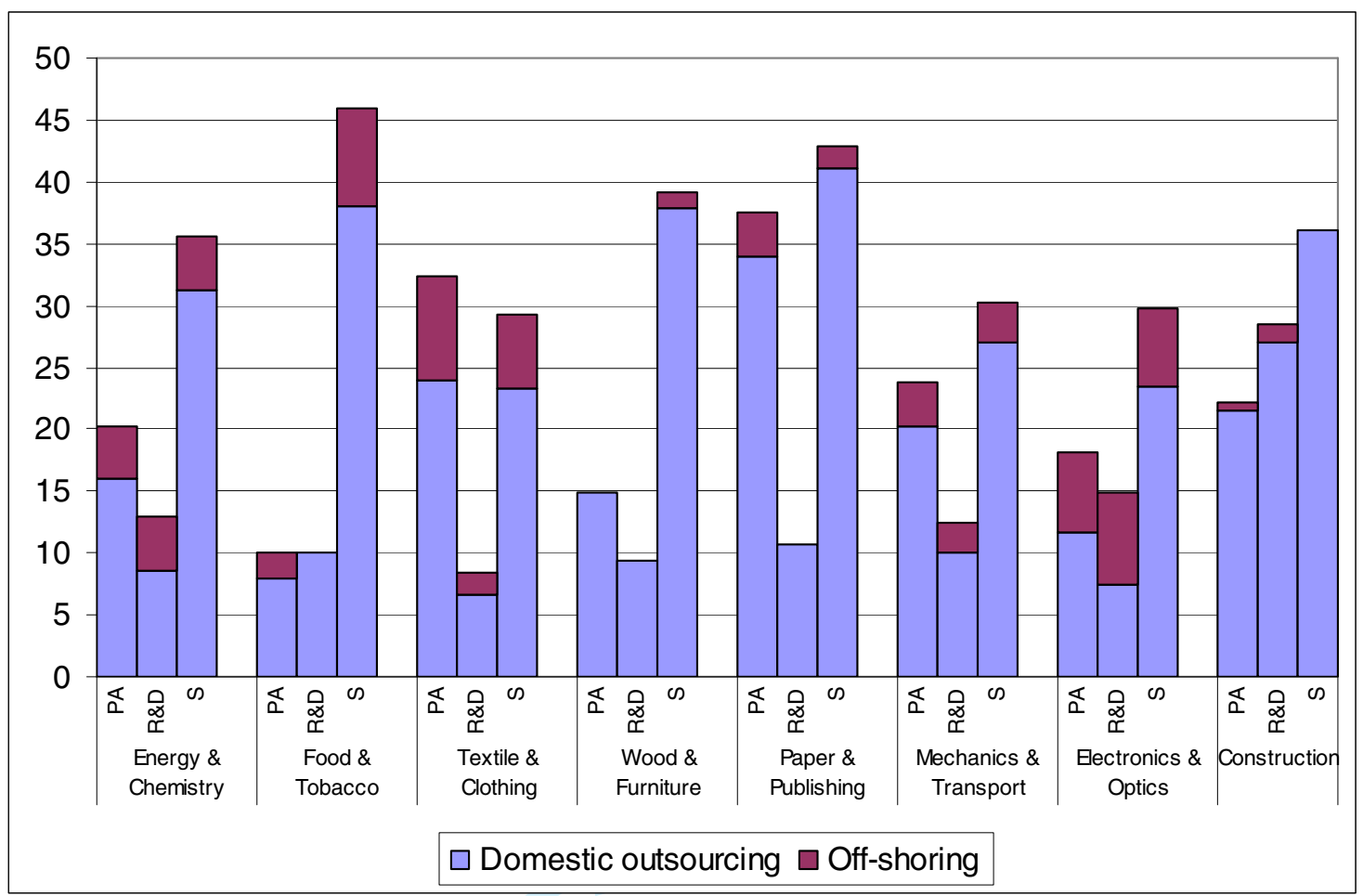


Table 1 - Sample composition

\begin{tabular}{lccccccc}
\hline Industry & $6-9$ & $10-49$ & $50-249$ & $250-499$ & $>500$ & Total & Response rate \\
\hline Energy \& Chemistry & 19 & 63 & 62 & 9 & 10 & 163 & 0.91 \\
Food \& Tobacco & 10 & 19 & 19 & 2 & 0 & 50 & 0.82 \\
Textile \& Clothing & 26 & 78 & 54 & 4 & 5 & 167 & 0.92 \\
Wood \& Furniture & 21 & 40 & 12 & 1 & 0 & 74 & 1.35 \\
Paper \& Publishing & 6 & 30 & 15 & 4 & 1 & 56 & 0.79 \\
Mechanics \& Transport & 59 & 193 & 113 & 21 & 14 & 400 & 0.89 \\
Electronics \& Optics & 18 & 45 & 27 & 3 & 1 & 94 & 0.79 \\
Construction & 43 & 79 & 19 & 3 & 0 & 144 & 1.76 \\
Total & 202 & 547 & 321 & 47 & 31 & 1,148 & 0.96 \\
\hline
\end{tabular}


Table 2 - Outsourcing, by industry (\% firms)

\begin{tabular}{lc|ccc}
\hline Industry & \% Outsourcers & \multicolumn{3}{|c}{ of which (share) } \\
\cline { 3 - 5 } & & Regional & National & Off-shorers $^{\circ}$ \\
& & Outsourcers* & Outsourcers & \\
\hline Energy \& Chemistry & 51.53 & 0.82 & 0.33 & 0.18 \\
Food \& Tobacco & 50.00 & 0.76 & 0.52 & 0.16 \\
Textile \& Clothing & 47.90 & 0.83 & 0.29 & 0.25 \\
Wood \& Furniture & 50.00 & 0.84 & 0.41 & 0.03 \\
Paper \& Publishing & 60.71 & 0.71 & 0.53 & 0.09 \\
Mechanics \& Transport & 48.25 & 0.84 & 0.30 & 0.16 \\
Electronics \& Optics & 42.55 & 0.75 & 0.30 & 0.33 \\
Construction & 54.17 & 0.95 & 0.15 & 0.04 \\
Total & 49.74 & 0.83 & 0.31 & 0.16 \\
\hline
\end{tabular}

*Firms outsourcing at least one activity within the region.

${ }^{\S}$ Firms outsourcing at least one activity in other Italian regions

${ }^{\circ}$ Firms outsourcing at least one activity abroad 
Table 3 - Depth of outsourcing, by function (\% of firms)

\begin{tabular}{lcccc}
\hline Function & $\begin{array}{c}\text { Never } \\
\text { performed }\end{array}$ & Totally & In-house and & In-house \\
& outsourced & outsourced & only \\
\hline Production/ & 2.96 & 3.05 & 20.30 & 73.69 \\
Assembling & & & & \\
R\&D/ Design & 25.70 & 6.36 & 7.40 & 60.54 \\
Services & 15.33 & 4.36 & 29.09 & 51.22 \\
\hline
\end{tabular}


Table 4 - Direction of outsourcing, by localisation (\% of potential outsourcers*)

\begin{tabular}{|c|c|c|c|}
\hline \multirow[t]{2}{*}{ Function } & \multirow[t]{2}{*}{$\%$ Outsourcers } & \multicolumn{2}{|c|}{ of which (share) } \\
\hline & & $\begin{array}{c}\text { \% Regional } \\
\text { Outsourcers }\end{array}$ & $\%$ Off-shorers ${ }^{\circ}$ \\
\hline Production/ Assembling & 24.06 & 0.73 & 0.17 \\
\hline R\&D/ Design & 17.71 & 0.72 & 0.18 \\
\hline Services & 39.51 & 0.85 & 0.11 \\
\hline
\end{tabular}

*Firms performing or having performed the function

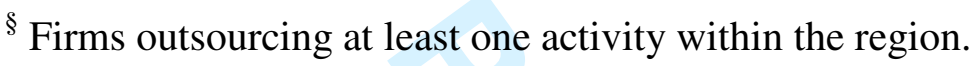

${ }^{\circ}$ Firms outsourcing at least one activity abroad 
Table 5 - Explanatory variables (in logs): descriptive statistics

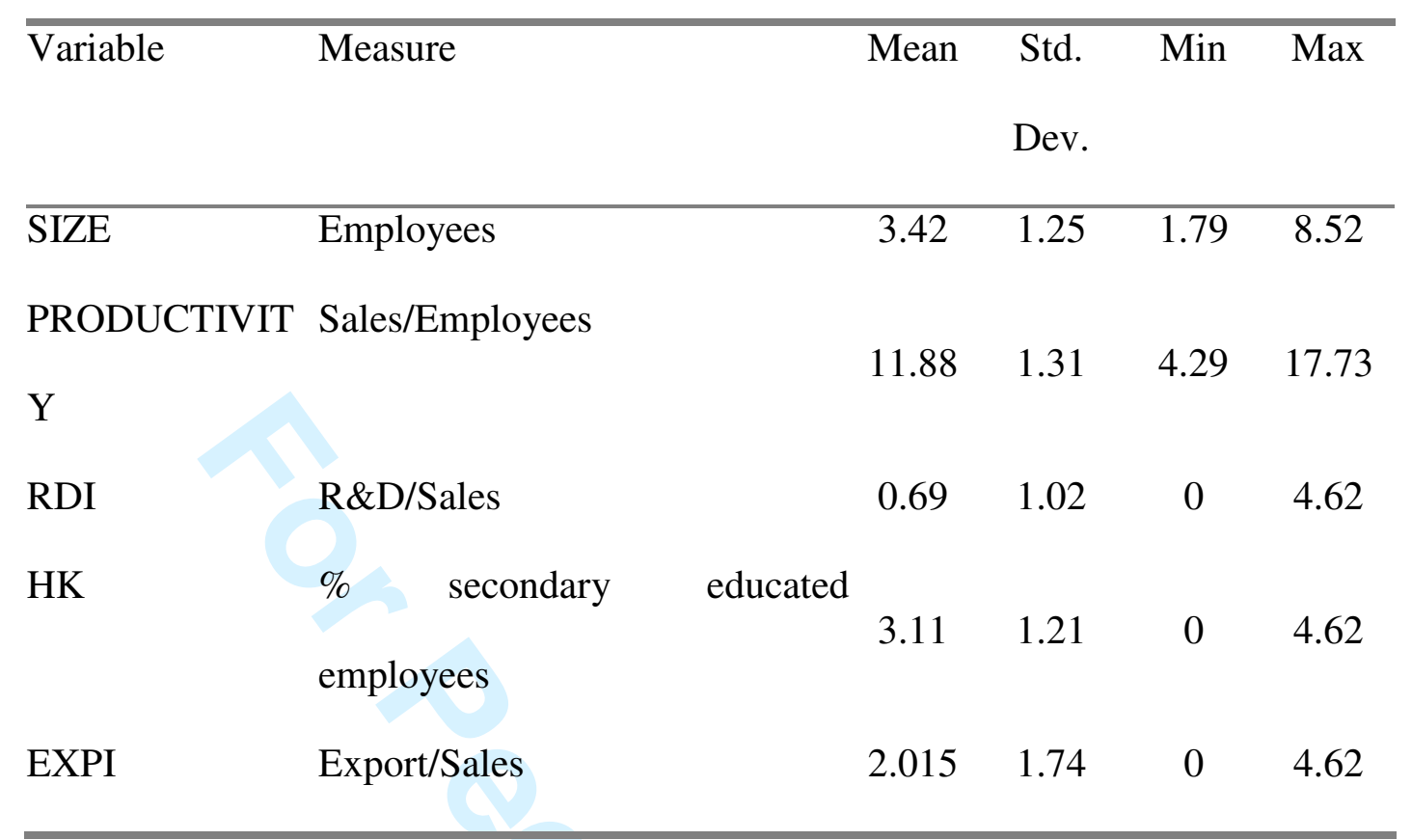


Table 6 - Correlations among explanatory variables

\begin{tabular}{|lccccc|}
\hline & SIZE & PRODUCTIVITY & RDI & EXPI & HK \\
SIZE & 1.000 & & & \\
PRODUCTIVITY & 0.145 & 1.000 & & & \\
RDI & 0.251 & 0.043 & 1.000 & & \\
EXPI & 0.415 & 0.066 & 0.296 & 1.000 & 1.000 \\
HK & 0.263 & 0.181 & 0.190 & 0.187 & \\
\hline
\end{tabular}


Table 7 - Estimation results

\begin{tabular}{|c|c|c|c|c|c|c|c|}
\hline & (1) & (2) & (3) & (4) & (5) & (6) & (7) \\
\hline & All outsourcing & $\begin{array}{l}\text { Exclusively } \\
\text { regional } \\
\text { outsourcing }\end{array}$ & $\begin{array}{c}\text { International } \\
\text { outsourcing }\end{array}$ & All outsourcing & $\begin{array}{l}\text { Exclusively } \\
\text { regional } \\
\text { outsourcing }\end{array}$ & $\begin{array}{c}\text { International } \\
\text { outsourcing }\end{array}$ & $\begin{array}{c}\text { International } \\
\text { outsourcing }\end{array}$ \\
\hline \multirow[t]{2}{*}{ Size } & -0.00 & -0.01 & $0.19 * * *$ & -0.01 & -0.00 & 0.10 & 0.07 \\
\hline & $(0.05)$ & $(0.05)$ & $(0.05)$ & $(0.05)$ & $(0.06)$ & $(0.07)$ & $(0.07)$ \\
\hline \multirow[t]{2}{*}{ Productivity } & 0.03 & -0.00 & 0.03 & 0.03 & 0.00 & 0.02 & 0.02 \\
\hline & $(0.04)$ & $(0.04)$ & $(0.06)$ & $(0.04)$ & $(0.04)$ & $(0.06)$ & $(0.06)$ \\
\hline \multirow[t]{2}{*}{ Rdi } & $0.08 *$ & -0.01 & 0.05 & 0.08 & -0.02 & 0.04 & 0.04 \\
\hline & $(0.05)$ & $(0.05)$ & $(0.06)$ & $(0.05)$ & $(0.05)$ & $(0.06)$ & $(0.06)$ \\
\hline \multirow[t]{2}{*}{$\mathrm{Hk}$} & $0.14 * * *$ & $0.10 * *$ & $0.21 * * *$ & $0.14 * * *$ & $0.10 * *$ & $0.19 * *$ & $0.19 * *$ \\
\hline & $(0.04)$ & $(0.04)$ & $(0.08)$ & $(0.04)$ & $(0.04)$ & (0.08) & $(0.08)$ \\
\hline \multirow{2}{*}{ Final product } & 0.16 & $0.25 *$ & $-0.49 * * *$ & 0.16 & $0.25 *$ & $-0.52 * * *$ & $-0.52 * * *$ \\
\hline & $(0.12)$ & $(0.13)$ & $(0.18)$ & $(0.12)$ & $(0.13)$ & (0.19) & $(0.19)$ \\
\hline \multirow[t]{2}{*}{ Expi } & & & & 0.03 & 0.03 & $0.11 * *$ & $0.12 * *$ \\
\hline & & & & $(0.03)$ & $(0.03)$ & $(0.05)$ & $(0.05)$ \\
\hline \multirow[t]{2}{*}{ Fdi } & & & & -0.09 & $-0.32 * *$ & $0.31 * *$ & \\
\hline & & & & (0.13) & $(0.14)$ & $(0.16)$ & \\
\hline Fdi_plant & & & & & & & $0.65 * *$ \\
\hline \multirow{2}{*}{ Fdi_sales } & & & & & & & $\begin{array}{c}(0.30) \\
0.41\end{array}$ \\
\hline & & & & & & & $(0.34)$ \\
\hline \multirow[t]{2}{*}{ Constant } & $-0.82 *$ & -0.53 & $-2.95 * * *$ & $-0.81 *$ & -0.59 & $-2.54 * * *$ & $-2.48 * * *$ \\
\hline & $(0.46)$ & $(0.47)$ & $(0.73)$ & $(0.46)$ & $(0.48)$ & $(0.79)$ & $(0.78)$ \\
\hline Industry dummies & yes & yes & Yes & Yes & yes & yes & yes \\
\hline F stat & 2.33 & 2.14 & 6.27 & 2.05 & 2.18 & 7.31 & 6.88 \\
\hline Prob $>F$ & 0.01 & 0.01 & 0.00 & 0.01 & 0.01 & 0.00 & 0.00 \\
\hline Obs. & 1099 & 1099 & 1099 & 1099 & 1099 & 1099 & 1099 \\
\hline
\end{tabular}

Standard errors in parentheses; * significant at 10\%; ** significant at 5\%; *** significant at $1 \%$ 
Table 7 cont. - Estimation results

\begin{tabular}{|c|c|c|c|c|c|c|c|}
\hline & $(8)$ & $(9)$ & $(10)$ & $(11)$ & $(12)$ & (13) & $(14)$ \\
\hline & All outsourcing & $\begin{array}{l}\text { Exclusively } \\
\text { regional } \\
\text { outsourcing }\end{array}$ & $\begin{array}{c}\text { International } \\
\text { outsourcing }\end{array}$ & All outsourcing & $\begin{array}{l}\text { Exclusively } \\
\text { regional } \\
\text { outsourcing }\end{array}$ & $\begin{array}{c}\text { International } \\
\text { outsourcing }\end{array}$ & $\begin{array}{l}\text { International } \\
\text { outsourcing }\end{array}$ \\
\hline \multirow[t]{2}{*}{ Size } & -0.01 & 0.01 & 0.04 & -0.01 & 0.01 & 0.06 & 0.05 \\
\hline & $(0.06)$ & $(0.06)$ & $(0.07)$ & $(0.06)$ & $(0.06)$ & $(0.07)$ & $(0.07)$ \\
\hline \multirow{2}{*}{ Productivity } & 0.03 & 0.00 & 0.01 & 0.04 & 0.01 & 0.00 & 0.00 \\
\hline & $(0.03)$ & $(0.04)$ & $(0.06)$ & $(0.04)$ & $(0.04)$ & $(0.06)$ & $(0.06)$ \\
\hline \multirow[t]{2}{*}{ Rdi } & 0.07 & -0.02 & 0.04 & 0.07 & -0.02 & 0.04 & 0.04 \\
\hline & $(0.05)$ & $(0.05)$ & $(0.06)$ & $(0.05)$ & $(0.05)$ & $(0.06)$ & $(0.06)$ \\
\hline \multirow[t]{2}{*}{$\mathrm{Hk}$} & $0.14 * * *$ & $0.10 * *$ & $0.17 * *$ & $0.14 * * *$ & $0.10 * *$ & $0.17 * *$ & $0.17 * *$ \\
\hline & $(0.04)$ & $(0.04)$ & $(0.07)$ & $(0.04)$ & $(0.04)$ & $(0.07)$ & $(0.07)$ \\
\hline \multirow[t]{2}{*}{ Final product } & 0.16 & $0.25 *$ & $-0.51 * * *$ & 0.16 & $0.25 *$ & $-0.51 * * *$ & $-0.53 * * *$ \\
\hline & $(0.12)$ & $(0.13)$ & $(0.19)$ & $(0.12)$ & $(0.13)$ & $(0.19)$ & $(0.19)$ \\
\hline \multirow[t]{2}{*}{ Expi } & 0.03 & 0.03 & $0.12 * *$ & 0.03 & 0.03 & $0.12 * *$ & $0.12 * *$ \\
\hline & $(0.03)$ & $(0.03)$ & $(0.05)$ & $(0.03)$ & $(0.03)$ & $(0.05)$ & $(0.05)$ \\
\hline \multirow[t]{2}{*}{ Fdi_plant } & -0.19 & $-0.75 * * *$ & $0.55^{*}$ & -0.20 & $-0.78 * * *$ & $0.58 *$ & $0.62 * *$ \\
\hline & $(0.22)$ & $(0.22)$ & $(0.30)$ & $(0.22)$ & $(0.22)$ & $(0.30)$ & $(0.30)$ \\
\hline \multirow[t]{2}{*}{ Fdi_sales } & -0.17 & -0.37 & 0.32 & -0.16 & -0.37 & 0.34 & 0.39 \\
\hline & $(0.32)$ & $(0.30)$ & $(0.36)$ & $(0.32)$ & $(0.30)$ & $(0.36)$ & $(0.35)$ \\
\hline \multirow[t]{2}{*}{ Group } & 0.10 & -0.03 & $0.32 *$ & & & & \\
\hline & $(0.15)$ & $(0.15)$ & $(0.17)$ & & & & \\
\hline \multirow[t]{2}{*}{ Group head } & & & & 0.25 & 0.39 & -0.30 & -0.31 \\
\hline & & & & $(0.25)$ & $(0.29)$ & $(0.27)$ & $(0.27)$ \\
\hline \multirow[t]{2}{*}{ Subsidiary } & & & & 0.07 & -0.13 & $0.40 * *$ & 0.26 \\
\hline & & & & $(0.16)$ & $(0.16)$ & $(0.18)$ & $(0.20)$ \\
\hline \multirow[t]{2}{*}{ Subsidiary*Foreign } & & & & & & & $0.59 *$ \\
\hline & & & & & & & $(0.34)$ \\
\hline \multirow[t]{2}{*}{ Constant } & $-0.79 *$ & -0.63 & $-2.34 * * *$ & $-0.80 *$ & -0.68 & $-2.27 * * *$ & $-2.21 * * *$ \\
\hline & $(0.46)$ & $(0.48)$ & $(0.76)$ & $(0.46)$ & $(0.48)$ & $(0.78)$ & $(0.78)$ \\
\hline Industry dummies & yes & yes & Yes & yes & yes & yes & Yes \\
\hline F stat & 1.83 & 2.41 & 6.83 & 1.76 & 2.34 & 6.59 & 6.56 \\
\hline Prob $>F$ & 0.02 & 0.00 & 0.00 & 0.03 & 0.00 & 0.00 & 0.00 \\
\hline Obs & 1099 & 1099 & 1099 & 1099 & 1099 & 1099 & 1099 \\
\hline
\end{tabular}


${ }^{\mathrm{i}}$ Corresponding author: Lucia Cusmano, Department of Economics, Insubria University, via Monte Generoso 71, 21100 Varese, Italy. Phone: +39 0332 395513; Fax +39 0332395509.

ii TOMIURA (2005) provides a concise review.

iii O'Farrell et al. (1993) define this process of vertical disintegration as "service unbundling".

${ }^{\text {iv }}$ For the sake of clarity and to ease interpretation, we shall present these relationships in detail in section 5.1, when discussing the structure of the empirical analysis on firm-level characteristics and the geographical scope of outsourcing.

${ }^{\mathrm{v}}$ Lombardy has been the focus of early investigations about flexible production systems and industrial district models, emerging in the late 1970s as a peculiar case of diffused industrial development based on SMEs (GAROFOLI, 1983).

vi The survey adopted a broad definition of $R \& D$, which is intended as any activity oriented towards research and experimentation.

vii $69 \%$ of firms off-shoring R\&D activities do so, at least partially, to a group affiliate. The corresponding figures for production and services are, respectively, $64 \%$ and $52 \%$. The difference is however more striking when considering firms off-shoring exclusively to group affiliates: these are $35 \%$ of firms offshoring R\&D, but only $2 \%$ of firms off-shoring production and $7 \%$ of firms off-shoring services. viii The survey specifically asked whether the firm produces a final good or an intermediate good. ${ }^{\text {ix }}$ Here the survey first asked if the firm has pursued any foreign direct investment, distinguishing between: (a) production facilities; (b) R\&D lab; (c) sales office.

${ }^{\mathrm{x}}$ In the survey, whenever the respondent declared the firm belonged to a group, he/she was asked to specify the position of the firm within the group.

${ }^{x i}$ In the regressions, all continuous variables are measured in logs: to treat observations with zero value in some of the relevant variables, we added one before taking the logarithm.

${ }^{x i i}$ Mol (2005) finds a positive and significant effect of productivity on outsourcing, however in his regressions the coefficient of productivity is effectively zero.

xiii This is again obtained from a survey question asking for the country of residence of the subjects retaining either the ownership or the control of the firm. 